\title{
"BEZ HAVRÁNKA SI NIKDO ANI NEŠKRTL."1 POVÁLEČNÉ VZTAHY KATEDRY ČESKÉHO JAZYKA PRAŽSKÉ FILOZOFICKÉ FAKULTY A AKADEMICKÉHO ÚSTAVU PRO JAZYK ČESKÝ*
}

\author{
VĚRA DVOŘÁČKOVÁ
}

\section{'WITHOUT HAVRÁNEK, NO ONE COULD DO ANYTHING.' POST-WAR RELATIONS BETWEEN THE DEPARTMENT OF CZECH LANGUAGE OF THE FACULTY OF ARTS IN PRAGUE AND THE INSTITUTE FOR CZECH LANGUAGE OF THE ACADEMY OF SCIENCES}

Post-war relations between the Department of Czech Language of the Faculty of Arts of Charles University and the Institute for Czech Language of the Academy of Sciences were very close, both in terms of research activities and in personal relations. Their nature was largely determined by Bohuslav Havránek, the most important linguist of Czechoslovakia of his time, a man who was able to skilfully and honourably navigate the maze of restrictions to which academic education and scientific research was subjected at that time.

Keywords: History of Bohemistics - Czech studies - Czechoslovak Academy of Sciences - Faculty of Arts of the Charles University - Bohuslav Havránek

DOI: $10.14712 / 23365730.2018 .12$

Vzájemný vztah a postavení katedry českého jazyka pražské filozofické fakulty a akademického Ústavu pro jazyk český byl v průběhu sledovaného období velmi úzký. Personální, potažmo vědecká provázanost byla převážnou měrou dána osobou nejvýznamnějšího lingvisty tehdejšího Československa, Bohuslava Havránka, který působil mj. jako děkan fakulty a vedoucí jazykovědně bohemistické katedry, tak i jako ředitel Ústavu pro jazyk český. Jeho pozice prvního muže československé lingvistiky vyplývala z jeho vůdčích schopností, vysoké odborné erudice, ale i jisté míry servility vůči režimu, který jej povětšinou vnímal jako svou oporu.

Cílem tohoto př́spěvku je nastínit a objasnit povahu vazeb obou dotčených pracovišt' v kontextu předchozího historického vývoje, soudobých událostí, dobové společenské atmosféry i vlivu a postavení klíčových osob tehdejš́ české lingvistiky.

* Studie vznikla v rámci projektu GA ČR 13-09541S Univerzita Karlova a Československá akademie věd. Instituce vědy a vysokoškolské vzdělanosti v proměnách politiky a společnosti v letech 1945-1968.

1 Rozhovor se Zoe Hauptovou, in: Jan ChromÝ - Eva LehečKová (edd.), Rozhovory s českými lingvisty, II, Praha 2009, s. 48. 


\section{Meziválečné konotace}

V obecnějším slova smyslu je třeba stav pražské poválečné bohemistické lingvistiky v první řadě usouvztažnit se dvěma zásadními momenty meziválečného období. Prvním je vznik Pražského lingvistického kroužku v roce 1926 a rozvoj jedné z prvních strukturalistických škol ve světě, tzv. Pražské školy, která si svým funkčně strukturním př́ístupem k jazyku vydobyla světové renomé a dodnes je považována za české/československé rodinné stř́ibro. ${ }^{2} \mathrm{~V}$ padesátých letech však byla opakovaně stavěna na pranýř, odkud se jen obtížně, avšak s o to větší rafinovaností dostávala. Plné rehabilitace se dočkala v zásadě až po roce 1989.

Druhou klíčovou skutečností sahající svými kořeny ještě před vznik samostatného Československa je činnost Kanceláře Slovníku jazyka českého ustavené při České akademii císaře Františka Josefa v roce 1911, jež se stala prrímým předchůdcem a jádrem budoucího Ústavu pro jazyk český. Její soustavnou a vytrvalou prací začal vycházet dosud nejrozsáhlejší slovník češtiny (Př́ručni slovník jazyka českého) a byla formulována první česká (a slovenská) lexikologická a lexikografická teorie. ${ }^{3}$ Není přitom bez zajímavosti, že prípravě a vydávání tohoto slovníku byla z pozice státu přikládána poměrně významná důležitost, což se odráželo i na finančním zabezpečení projektu. Roli přitom hrála jak společenská poptávka po moderním českém výkladovém slovníku, tak i jeho státotvorný potenciál dotvářející vydobytou a stále obhajovanou národní ideu postavenou mj. i na národním jazyce.

Jméno Bohuslava Havránka je spjato jak s Pražskou školou, jíž byl čelný představitel (předválečný i poválečný), tak i s Příručním slovníkem jazyka českého. V Kanceláři Slovníku jazyka českého v letech 1915-1929 pracoval a roku 1942 se stal vedoucím redaktorem Slovníku.

\section{Ústav pro jazyk český}

Ihned po skončení druhé světové války počala přednostně péčí Bohuslava Havránka získávat reálné kontury předválečná snaha o vznik komplexního ústavu jazykovědné bohemistiky. Na rozdíl od většiny ostatních společenskovědních oborů bylo na čem stavět. Vedle již zmiňované Kanceláře Slovníku jazyka českého, jejíž činnost byla formálně rízena lexikografickou komisí České akademie věd a umění (ČAVU), rozvíjely jazykovědně bohemistickou činnost také další akademické komise: dialektologická, fonografická, ortoepická, fonetická, bibliografická, místopisná, pravopisná, širší bohemistická, komise pro gramatickou terminologii, komise pro vydávání spisů profesora Oldřicha Hujera, komise pro vydávání spisů J. A. Komenského, komise pro vydání nejstarších legend, komise pro studium staročeské bible či komise pro fotografování rukopisů a starých tisků. ${ }^{4}$

2 Viz např. Rozhovor s Františkem Čermákem, in: J. ChromÝ - E. LeHEČKovÁ (edd.), Rozhovory s českými lingvisty, III, Praha 2010, s. 28.

3 Alois Ziskal, Př́spěvky k lexikografické teorii a praksi, Slovo a slovesnost (dále SaS) 4/a, 1938, s. 19-27; TY̛ž, Dalši př́spěvek k lexikografické teorii a praksi (Vícevýznamovost slov), SaS 4/b, 1938, s. 149-160; TY̛ž, Závěrečný prŕíspěvek k lexikografické teorii a praksi, SaS 4/c, 1938, s. 212-222.

4 Věra DvořÁčKovÁ, K činnosti komisí fonografické, ortoepické a fonetické České akademie věd a umění, Práce $\mathrm{z}$ dějin Akademie věd 6/1, 2014, s. 47. 
Ústav pro jazyk český (ÚJČ) byl při ČAVU zř́zen 6. února 1946 a z Kanceláře Slovníku jazyka českého se stalo jeho lexikografické oddělení. Ústav v první fázi zahrnul i výzkum dialektologický a terminologický, studium nové spisovné češtiny i vývoje jazyka a sestavování bibliografie české jazykovědy, nicméně až do roku 1949 téměř nedisponoval vlastními stálými zaměstnanci a musel spoléhat na udělování úplných či částečných dovolených pro středoškolské učitele ze strany ministerstva školství, věd a umění.

Ústav pro jazyk český vznikl jako vůbec první akademický ústav a o rok později byl následován Ústavem pro českou literaturu, kde se Bohuslav Havránek rovněž angažoval: „Mnoho času mi bere Ústav pro jazyk český při Čs. akademii [...]. Tento rok bylo také mnoho starostí s rodicím se Ústavem pro čes. literaturu (hlavně aby Mukařovský a pak jeho žáci tam méli vliv a možnosti) [...]“.5

Události roku 1948 bezprostředně zasáhly i do vlastní vědecké práce ÚJČ. Při výběru literatury určené k excerpci pro synchronní slovníky se musela začít výrazně akcentovat marxisticko-leninská a budovatelská literatura, což některým dosavadním dlouholetým excerptorům nejspíš nebylo po vůli. Ukončení jejich spolupráce komentoval Bohuslav Havránek slovy, že „často je těžko žádat, aby penzista byl pokrokovy““. 6 Pod Havránkovou taktovkou byly také přehodnocovány citace $\mathrm{v}$ dosud nevydaných dílech Př́ričního slovníku jazyka českého, když byli mezi nepřijatelné autory postupně přiřazováni např. Ivan Blatný, Václav Černý, Jakub Deml, Jaroslav Durych, Viktor Dyk, Svatopluk Machar, Rudolf Medek, A. C. Nor, Ferdinand Peroutka či Milada Součková.

Ještě před vznikem Československé akademie věd přicházeli z Ústavu pro jazyk český ČAVU i jemu předcházející Kanceláře Slovníku jazyka českého na vysoké školy v Praze, Brně i Olomouci kvalitní vědecké posily využívající při pedagogické i vědecké práci svých zkušeností nabytých v akademii. Patřili k nim František Trávníček, Miloš Weingart, Václav Machek, Josef Miloslav Kořínek, Josef Kurz, Karel Horálek, Quido Hodura, Alois Jedlička, František Jílek-Oberpfalcer, Jaromír Bělič, František Kopečný i sám Bohuslav Havránek. ${ }^{7}$

\section{Seminár̆ pro slovanskou filologii a studijní prověrky}

Poté, co skončila druhá světová válka a české vysoké školy se znovu otevřely, vyvíjela se velká snaha vysoké školství co nejrychleji konsolidovat a situace na pražské filozofické fakultě nebyla výjimkou. Již v průběhu prvního poválečného akademického roku 1945/1946 zde byli jmenováni noví řádní profesoři, přičemž jako prvnímu (25. září 1945 se zpětnou účinností od 1. 6. 1945) byl jmenovací dekret udělen dosavadnímu řádnému profesoru brněnské filozofické fakulty Bohuslavu Havránkovi pro obor srovnávací slovanské jazykovědy. ${ }^{8}$

5 Marie HavránKová - Jindřich Toman (edd.), Quadrilog (Bohuslav Havránek, Zdeňka Havránková, Roman Jakobson, Svatava Pirková-Jakobsonová). Vzájemná korespondence 1930-1978, Praha 2001, s. 77.

6 Masarykův ústav a Archiv AV ČR, v. v. i. (dále jen AAV ČR), fond Ústav pro jazyk český České akademie věd a umění (dále ÚJČ ČAVU), k. 2, i. č. 18, Protokol o pracovní schůzce zaměstnanců ÚJČ́, 31. 3. 1950.

7 Bohuslav HaVRÁNEK, Vybudováni nové Československé akademie věd a Ústav pro jazyk český, Naše řeč 36/1-2, 1953, s. 25.

8 Národní archiv (dále jen NA), fond Ministerstvo školství a kultury, Praha - osobní spisy, k. 45, sign. B. Havránek, jmenovací dekret zaslaný rektorátu UK Úřadem předsednictva vlády na základě rozhodnutí presidenta republiky o jmenování Bohuslava Havránka řádným profesorem FF UK, 1. 10. 1945. 
Vzápětí se Havránek stal náměstkem ředitele semináře a prosemináře pro slovanskou filologii Filozofické fakulty Univerzity Karlovy, Alberta Pražáka. ${ }^{9}$

Návrat k předválečným vysokoškolským tradicím nebyl od počátku nijak jednoduchý, ovšem postupně se ukazoval stále nepravděpodobnějším. V prvních poválečných letech nastoupilo do studia velké množství studentů - těch, kterým studium přerušily válečné události, těch, kteří by byli začali po roce 1939 studovat, i těch, kteří právě odmaturovali. Naproti tomu pedagogický sbor se v řadě oborů nepodařilo dostatečně zajistit, jak vyplývá např. z dopisu Bohuslava Havránka z 12. 6. 1947 Romanu Jakobsonovi do USA: „Na fakultě na obec. [obecné] slavistice (ling. [lingvistické] i liter. [literární]) a rusistice bylo 1937 pět řádných profesorů a nyní jsem s Boh. Mathesiem sám [...]“. ${ }^{10}$

Únor 1948 pak na vysokých školách odstartoval sérii opatření, jež měly vést k vytvoření podpůrného systému nového režimu a jeho ideologického zázemí. Počátkem zimního semestru byl do čela Karlovy univerzity uveden literární teoretik a estetik Jan Mukařovský a děkanem její filozofické fakulty se stal lingvista Bohuslav Havránek. Oba byli členy komunistické strany a v př́padě obou se zdály být jejich odborné kvality ve vyváženém poměru k jejich prorežimní loajalitě, ačkoli hned roku 1949 vůči nim vznesl sovětský historik P. G. Sofinov při své návštěvě Univerzity Karlovy adresnou kritiku, že „,mají daleko k tomu, aby ve svém každodenním vědeckém životě aplikovali marxismus" s tím, že nejen oni se mylně domnívají, že pouze svým vstupem do KSČ se z nich stali marxisti. ${ }^{11}$

S př́ichodem Mukařovského a Havránka se ihned začalo jednat o reformě studia, která vešla v platnost v následujícím akademickém roce 1949/1950, do něhož ve srovnání s prvními poválečnými lety nastoupil značně redukovaný počet studentů. Při přijímacím řízení rostl význam třídního původu a třídního uvědomění uchazečů, mezi nimiž se poprvé objevovali již také absolventi tzv. dělnických kurzů v duchu Gottwaldova prohlášení na 9. sjezdu KSČ o tom, že ,dělnická tř́lda si musí vytvořit a vzdělat svoji vlastní inteligen$c i^{\text {“ }}, 12$ ideologicky s ní spjatou a lidu ze všech sil obětavě pomáhající, ${ }^{13}$ jak ve svém spisku doplnil komunistický ideolog Ladislav Štoll.

Reforma zaváděla povinné studijní kroužky, stanovovala počet a schválený obsah povinných přednášek (mezi nimiž na prvním místě figuroval marxismus-leninismus), přesný plán zápočtů a dílčích zkoušek a také oddělovala učitelskou a odbornou studijní větev. Z větší části se prosazovaly „principy, které byly v př́mém rozporu s dřivějšími akademickými tradicemi“. 14

Počínaje únorem 1948 byly vysoké školy v tomto a nadcházejícím roce podrobeny první vlně studijních prověrek organizovaných ministerstvem školství skrze akční výbory Národní fronty, jež měly ,odstranit flákače a reakčníky a změnit třídní složení vysokoškolákư““. ${ }^{15}$

9 Jan Havránek - Zdeněk Pousta, Dějiny Univerzity Karlovy, IV, 1918-1990, Praha 1998, s. 436.

10 M. HavránKová - J. Toman (edd.), Quadrilog, s. 76.

11 John ConNely, Zotročená univerzita. Sovětizace vysokého školství ve východním Německu, včeských zemích a v Polsku v letech 1945-1956, Praha 2008, s. 96.

12 Miroslav Somr a kol., Dějiny školství a pedagogiky, Praha 1987, s. 305.

13 Ladislav ŠToll, O socialistickou inteligenci, Praha 1949, s. 10-11.

14 Martina Šmejkalová, Praporu věren i ve ztraceném boji. Vladimír Šmilauer - život a dílo filologa (1895-1983), Praha 2015, s. 119.

15 Markéta Devátá, Přispěvek $k$ dějinám vysokých škol v letech 1948-1950 na základě dobových dokumentů, in: Antonín Kostlán (ed.), Semináře a studie výzkumného centra pro dějiny vědy z let 2002-2003, Praha 2003, s. 632 . 
Členy akčních výborů byli radikálně naladění, prorežimně smýšlející studenti, kteří byli „neúnavní, operativní a připraveni rychle a účinně zasáhnout na pokyn ř́dících orgánů $K S C^{\prime \prime}{ }^{16}$ Řada z nich následně vstupovala i do pedagogických sborů, akademických senátů, disciplinárních komisí apod., ${ }^{17}$ čímž docházelo $\mathrm{k}$ hrubému narušování svébytnosti akademických orgánů. Bortily se „tradiční jistoty akademické obce, ubývalo vzájemné tolerance vědeckých škol a směrù, kvalifikovaných diskusí a učených hádáni" ${ }^{\prime 18}$ Toto vměšování studentů do řízení vysokých škol na přelomu 40. a 50. let 20. století dostalo posléze označení studentokracie či klukokracie, ${ }^{19}$ jejiž představitelé na filozofických fakultách byli obzvláště agilní. Hlavní disciplinární komisi na Filozofické fakultě Univerzity Karlovy předsedala studentka Milena Bláhová, jejím tajemníkem byl student lingvistiky Petr Sgall a za pedagogy zde působil mladý sociolog Miloš Kaláb. ${ }^{20}$

Pozornost akčních výborů tu byla věnována zejména oborům filozofie, sociologie, historie a jazykovědné i literárněvědné bohemistiky, ačkoli právě v posledních dvou zmiňovaných disciplínách byly důsledky prověrek významně korigovány působením Bohuslava Havránka a Jana Mukařovského. Profesor srovnávací literatury Václav Černý a profesor anglické řeči a literatury Otakar Vočadlo sice za obět' nevybíravým čistkám padli, Havránkovým přičiněním však byli naopak ušetřeni profesor rusistiky Leontij Kopeckij a soukromý docent ukrajinštiny Ivan Paňkevič. ${ }^{21}$

\section{Katedra českého jazyka, obecného jazykozpytu a fonetiky}

V květnu roku 1950 vyšel nový vysokoškolský zákon (zákon ze dne 18. 5. 1950 o vysokých školách č. 58/1950 Sb.), který odrážel požadavek reorganizace vnitřního uspořádání československých vysokých škol po vzoru těch sovětských ${ }^{22}$ a okleštoval jejich již tak značně omezenou autonomii. Byl mj. zrušen akademický senát a od akademického roku 1950/1951 byly ministrem školství zakládány katedry nahrazující tradiční stolice spjaté s osobami konkrétních profesorů. Důležité slovo měl při vytváření nového uspořádání filologických oborů (zejména srovnávací slovanské jazykovědy, rusistiky, bohemistiky, obecného jazykozpytu a fonetiky) a jejich personálního zabezpečení na pražské filozofické fakultě Bohuslav Havránek, jenž ve školních letech 1948/1949-1950/1951 zastával funkci děkana a ujal se rovněž vedení nově ustavené katedry českého jazyka, obecného jazykozpytu a fonetiky, kde se mu podařilo soustředit kvalitní pedagogickou základnu, již tvořili Vladimír Skalička, František Ryšánek, Václav Vážný, Bohumil Mathesius či Vladimír Šmilauer. ${ }^{23}$

16 Zdeněk Pousta, Perzekuce studentů Univerzity Karlovy po roce 1948, Documenta Pragensia 11, Praha 1994, s. 238.

17 Pavel URBášEK, Čistky na českých vysokých školách v letech 1945-1990, in: Marie Černá - Jaroslav Cuhra (edd.), Prověrky a jejich místo v komunistickém vládnutí. Československo 1948-1989, Praha 2012, s. 124.

18 Čestmír Císař, Paměti nejen o zákulisi Pražského jara, Praha 2005, s. 263.

19 Viz např. Marie ČERnÁ - Jaroslav CuHRA (edd.), Prověrky a jejich misto v komunistickém vládnutí. Československo 1948-1989, Praha 2012.

20 Jakub JAREš, ,,Indiferentní - možnost převýchovy! “ Cíle tzv. studijní prověrky na vysokých školách a jejich realizace, in: M. Černá - J. Cuhra (edd.), Prověrky a jejich místo, s. 36.

21 J. HavráneK - Z. Pousta, Déjiny Univerzity Karlovy, IV, s. 440-441.

22 M. Devátá, Př́spěvek k dějinám, s. 632.

23 M. ŠMEJKaLová, Praporu věren, s. 119. 
Situace, kdy se katedře českého jazyka ve větší míře zásahy státní moci vyhnuly, bývá mnohdy usouvztažňována s menší ideologickou a politickou zatížeností jazykovědné bohemistiky. ${ }^{24}$ Filozofie, historie i literární věda patřily mezi disciplíny podstatně exponovanější. Nepochybně zde však velkou úlohu hrála také Havránkova vzrůstající autorita.

\section{Rozdělení Filozofické fakulty Univerzity Karlovy}

Jak již bylo výše uvedeno, instalací Jana Mukařovského a Bohuslava Havránka do rektorské, respektive děkanské funkce si nový režim sliboval upevnění svých pozic na univerzitě. Z vládního nařízení z 2. října 1951 nicméně vyplývá, že s poměry na pražské filozofické fakultě spokojenost nepanovala, ${ }^{25}$ což nepochybně souviselo i se zdrženlivým přístupem, který zejména děkan Havránek zaujímal při studijních prověrkách (obzvláště na jazykovědných oborech).

Ve snaze zajistit si požadovanou míru vlivu a kontroly došlo na vládní úrovni k rozhodnutí vytvořit zde menší, jednodušeji ovladatelné celky. Filozofická fakulta Univerzity Karlovy se tak pro studijní roky 1952/1953-1958/1959 rozdělila na fakulty dvě: filologickou a filozoficko-historickou, i když vzájemná provázanost jejich studijních i čistě organizačních aspektů výrazných změn nedoznala. Filologickou fakultu vedl v prvním roce její existence Bohuslav Havránek, jemuž při výběru spolupracovníků záleželo výsostně na jejich odborných kvalitách. Oddělení českého jazyka vedl František Ryšánek (dále tu byl Vladimír Šmilauer, Václav Vážný a od roku 1957 Jaromír Bělič), obecný jazykozpyt měl pod taktovkou Vladimír Skalička (v roce 1956 sem přišel Pavel Trost) a oddělení fonetiky bylo v rukou Bohuslava Hály (vedle něj zde působila též další výrazná osobnost české fonetiky Milan Romportl). ${ }^{26}$

Po odhalení kultu Stalinovy osobnosti v roce 1956 přichází krátké období uvolnění, kdy se studenti ve větším měřítku odhodlávají ke kritice poměrů na fakultě, ovšem hned v následujícím období (1957-1958) byly podniknuty určité kroky kladoucí si za cíl pozici režimu upevnit. Ačkoli se ukázalo, že na rozdíl od jiných vysokých škol (např. Vysoké školy chemicko-technologické či Univerzity Palackého v Olomouci) se nastoupivší celostátní prověrky politické a třídní spolehlivosti Univerzity Karlovy komplexně nedotkly, jisté stranické zásahy byly pocítěny i zde. ${ }^{27}$ Jazykovědná bohemistika na filologické fakultě se v jejich důsledku musela rozloučit s Františkem Ryšánkem, vůči němuž byl uplatněn $\S 26$ odst. 8 novely zákona č. 46/1956 Sb. o penzionování vyučujících starších 70 let, a Václavem Vážným, nekomunistou starším 65 let. Jejich odchod z univerzity byl součástí hromadné akce, kdy na fakultě našla uplatnění řada mladých odborných asistentů, dočkavších se na přelomu 50. a 60. let habilitace. Patřili mezi ně i jazykovědci Petr Sgall (1958), Karel Hausenblas (habilitován 1961) či Karel Svoboda (docentem od roku 1964).

Bohuslav Havránek nicméně Ryšánkovi a Vážnému ponechal možnost dále se účastnit prací na Staročeském slovníku, respektive na dialektologických bádáních v rámci ÚJČ.

24 Jiř́ Holý - Katka VolnÁ, Tato fakulta bude rudá!, Praha 2010.

25 J. Havránek - Z. Pousta, Dějiny Univerzity Karlovy, IV, s. 446.

26 Tamtéž, s. 450.

27 Petr CAJTHAML - Marek ĎuRČAnSKÝ, Dobové souvislosti a ohlas prověrek politické a třidni spolehlivosti v roce 1958 na Univerzitě Karlově, Práce z dějin Akademie věd 2/2, 2010, s. 124. 


\section{Vznik Československé akademie věd}

V listopadu roku 1952 byla založena Československá akademie věd (ČSAV), která sice vznikla v důsledku snah režimu o zřízení centrální vědecké organizace po sovětském vzoru, avšak nelze tu nevidět zřetelnou vysokou míru návaznosti na činnost dosavadních vědeckých organizací, zejména sítě ústředních výzkumných ústavů, i propojenosti s univerzitními pracovišti. Straničtí ideologové předpokládali, že na rozdíl od vysokých škol, které se ideologické přestavbě (zcela) podř́idit nepodařilo, by novou akademii mohli od kořenů přizpůsobit svým představám. Jednoznačným zastáncem koncepce kontinuity s předchozím vývojem však byl první prezident ČSAV Zdeněk Nejedlý, člen vlády, a tak se nová akademie navzdory plánům režimních ideových tvưrců ryze politickou a ideologickou organizací nestala. ${ }^{28}$

Na vzniku a činnosti Československé akademie věd byl zpočátku vpravdě rozhodující podíl Univerzity Karlovy. Ve Vládní komisi pro vybudování ČSAV usedlo 27 čelných představitelů domácí vědecké scény, $\mathrm{z}$ nichž převážná většina působila $\mathrm{v}$ dané době na Karlově univerzitě. ${ }^{29}$ Místopředsedou komise byl jmenován Bohuslav Havránek, jenž se vzápětí stal i jedním z prvních 52 řádných členů nové akademické instituce. Filozofická fakulta Univerzity Karlovy měla přitom ve vztahu k ČSAV vůbec zásadní postavení, když se prvním prezidentem akademie stal profesor FF UK Zdeněk Nejedlý a jedním ze dvou místopředsedů archeolog Jaroslav Böhm, rovněž profesor FF UK.

Významní vysokoškolští představitelé, a to včetně těch, kteří byli podrobeni šikaně akčních výborů, nacházeli díky Zdeňku Nejedlému, jenž měl zájem shromáždit kolem sebe mezinárodně uznávané vědce, $\mathrm{v}$ ČSAV uplatnění. ${ }^{30}$ Jejich přičiněním a také pod vlivem požadavku prvního zákona o ČSAV, že má nová akademie přispívat po vědecké stránce též $\mathrm{k}$ rozvoji činnosti veškerých institucí do ní nezačleněných, se v mnoha oborech začala rozvíjet plodná spolupráce ČSAV a vysokoškolských pracovišt’ téhož či podobného zaměření. Rídící a vrcholná koordinační činnost $\mathrm{v}$ oblasti základního výzkumu a vědeckých úkolů stěžejního hospodářského významu ČSAV, stejně tak i její přední pozice v mezinárodních vědeckých stycích, výslovně daná změnou zákona o ČSAV z roku 1957, ${ }^{31}$ tento trend jen potvrdila.

Není pochyb o tom, že od rozdělení vědeckovýzkumné činnosti mezi akademii a vysoké školy 32 režim očekával snadnější kontrolu všech dotčených pracovišt'. Navíc vysoké školy, kde novou, tzv. socialistickou inteligenci může prozatím vychovat jedině stará inteligence, „která v sobě zcela logicky nese vlivy své buržoasní ideologické výchovy“, 33 bylo třeba mít pod zvláštním drobnohledem, mj. i skrze akademii věd.

28 Soňa ŠtrbáŇ́ová - Antonín Kostlán (edd.), Sto českých vědců v exilu: encyklopedie významných vědcũ z řad pracovniků Československé akademie věd v emigraci, Praha 2011, s. 57.

29 Soňa Spurná, Univerzita Karlova a Československá akademie véd, Zprávy z Archivu Univerzity Karlovy 25/1-2, 1985, s. 135.

30 Josef Petrán, Filozofové dělaji revoluci. Filozofická fakulta Univerzity Karlovy během komunistického experimentu (1948-1968-1989), Praha 2015, s. 224.

31 Miroslav ŠMIDÁK, Institucionální vývoj Československé akademie věd v letech 1960-1969 očima jednoho z př́mých aktérů, Praha 2011, s. 19.

32 V oblasti technických a prírodních věd zde významnou roli hrály též rezortní výzkumné ústavy.

33 NA, fond KSČ - Ústřední výbor 1945-1989, sv. 22, arch. j. 35/1-6, těsnopisný záznam ze zasedání ÚV KSČ 3.-5. prosince 1953, s. 78. 


\section{Ideologické sevření}

Jak poznamenal Čestmír Císař v souvislosti s převratnými změnami nastoupivšími po roce 1948, „co přicházelo z Moskvy, bylo jedině $k$ věreni"“. ${ }^{34}$ A tak když se v ruské, bezprostředně poválečné lingvistice začala prosazovat koncepce tzv. „nového učení o jazyce“, vycházející z teoretického podhoubí myšlenek gruzínského kavkazologa Nikolaje Jakovleviče Marra, nebylo pro československé lingvisty navzdory její scestnostij3 možné se její př́mé konfrontaci vyhnout. Obzvláště v situaci, kdy byl marrismus označován jako jediný správný marxistický př́stup $\mathrm{k}$ jazykovědě, vůči němuž byly do opozice stavěny všechny tzv. idealistické buržoazní směry (včetně strukturalismu), byla reakce našich předních lingvistů prímo vyžadována.

Hlavním propagátorem marrismu u nás byl Ctirad Bosák, jenž inicioval vznik překladového sborníku Sovětská jazykověda.$^{36}$ Prostřednictvím této publikace a přednášky Marrova žáka Ivana Ivanoviče Meščaninova, ${ }^{37}$ který v první polovině listopadu 1949 v Praze přednesl podrobný výklad Marrových tezí, bylo „nové učení o jazyce“ oficiálně představeno české veřejnosti. Na př́kladu Meščaninovovy přednášky ve velké posluchárně pražské filozofické fakulty je ve vzpomínce Zoe Hauptové trefně ilustrována absurdita slepého následování sovětského vzoru, stejně jako šiŕící se atmosféra strachu po roce 1948: „,Měl přednášku ve velké posluchárně na filozofické fakultě a všichni jsme tam museli přijit, až byla velká posluchárna plná. Byl tam sám velký Zdeněk Nejedlý a také všichni koryfejové české jazykovědy, brněnský František Trávníček, který pro marrismus doslova hořel, Bohuslav Havránek a další. Když skončila přednáška, mèla nastat diskuse. Jako první se přihlásil profesor Karel Horálek a prohlásil, že jemu připadá učení o nesprávnosti historickosrovnávaci metody a neexistenci genetického vývoje jazyků z indoevropského prajazyka a slovanských jazyků z praslovanštiny nemožné. ̌̌íkal, že si přes všechny soudobé výklady nedovede představit, že by slovanské jazyky nepocházely z jednoho základu. Marr totiž učil, že neexistuji jazykové rodiny, nýbrž že nové jazyky vznikají vzájemným mišsením jazyků existujicich. Horálek to tedy velmi stručně uvedl v pochybnost, načež nastalo hluboké a rozpačité ticho. Pak vystoupil velký Zdeněk Nejedlý, podival se očima po celé posluchárně a řekl, že když se divá po př́tomných, vidi každému na tvári jeho třídní pưvod. Nevím, co pak následovalo, snad nějaké chvalozpěvy, ale když jsem poté Horálka potkala na chodbě, řekl: ,Vite, já jsem mél pravdu a ten Trávníček mi potom ani ruku nepodal! ‘"“38

Bohuslav Havránek zaujal již v roce 1948 k marrismu vstřícně rezervovaný postoj, když se pokoušel hledat jeho styčné prvky ve vztahu k pražské funkčně-strukturální škole. ${ }^{39} \mathrm{~V}$ omezeném smyslu byl ochoten akceptovat např. konvergenci při vývoji národních

34 Čestmír Císař, Paměti nejen o zákulisí Pražského jara, Praha 2005, s. 296.

35 Jedním ze základních principů marrismu bylo učení o tzv. jafetických jazycích, které se považovaly za nejstarší a jejichž „křížením“ měly vzniknout všechny ostatní jazyky. Tato teorie zcela popírala př́ibuznost jazykových rodin a odmítala historickosrovnávací metodu v jazykovědě. Další základní teze hovořila o tzv. stadiálnosti jazykového vývoje, podle níž se jazyk vyvíjí v součinnosti s ekonomickým vývojem společnosti, opírajíc se přitom o představu náhlých násilných zvratů.

36 Sovětská jazykovéda: preklady vybraných studii N. J. Marra [a j.], Praha 1949.

37 Ivan Ivanovič MeŠČAnINOv, „Nové učení o jazyku“ v SSSR v jeho současné vývojové fázi, SaS 11/1, 1949, s. $1-7$.

38 Rozhovor se Zoe Hauptovou, in: J. Chromý - E. LeheČKová (edd.), Rozhovory, II, s. 43.

39 Bohuslav Havránek, Naše pojetí slovanské filologie a její dnešni úkoly, Slavia 18, 1948, s. 264-268. 
jazyků, nebot' se sám zabýval balkánským jazykovým svazem. Tento jeho počin se však nedlouho poté, kdy byl marrismus svrháván do propadliště dějin, ukázal být velmi neštastným. Kupř́kladu stranický ideolog a novinář Gustav Bareš v roce 1951 napsal: „Dokonce někteři soudruzi říkají, že kdyby se z Meščaninova odstranila marxistická frazeologie, byl by to - pokud jde o metodu - do značné míry strukturalismus. " 40

Již v polovině roku 1950 došlo v Sovětském svazu k obratu o plných sto osmdesát stupňủ. Vůči marrismu se vymezil sám Josif Vissarionovič Stalin, který nejspíše vyslyšel oprávněné obavy ze škodlivého a mezinárodně kompromitujícího charakteru Marrových divokých teorií vůči sovětské lingvistice. ${ }^{41} \mathrm{~V}$ sovětském tisku se odehrála ostře vedená polemika zastánců a odpůrců „nového učení“, již ukončil právě Stalin jednoznačným odsudkem marristické „vulgarizace marxismu“42 a rozborem „protimarxistických chyb“.43 Ještě v témže roce vyšly Stalinovy články v češtině, a to díky brysknímu překladu redakčního kolektivu Rudého práva v podobě útlé knížky $O$ marxismu v jazykovědě. ${ }^{44}$

Stalinovy stati o jazyce a jazykovědě, jejichž (spolu)autorem je pravděpodobně Arnold Stěpanovič Čikobava (či snad Viktor Vladimirovič Vinogradov, popř. oba), jsou sepsány věcně, stručně, v některých ohledech až naivně, avšak logiku nepostrádají. Došlo díky nim zejména $\mathrm{k}$ rehabilitaci historickosrovnávací metody, $\mathrm{k}$ odmítnutí náhlých násilných zvratů ve vývoji jazyka i jeho třídní povahy. Nepatřičným však bylo, že byly tyto teze pokládány za ucelenou lingvistickou teorii, což však plně korespondovalo s daným obdobím, kdy glorifikace sovětského „otce národů a učitele“45 dosahovala svého vrcholu. Údajná univerzální povaha Stalinových jazykovědných tezí však všeobjímala nejen jazykovědu, ale začala být vztahována i na nejrůznější (vědní) obory a oblasti lidské činnosti, s lingvistikou př́ibuzné i lingvistice zcela vzdálené: „Kdysi, v polovině padesátých let, jsem přišel k zubaři. Zubar̆ si někde přečetl, co dělám nebo co studuju, a zeptal se mě hned na Stalinovy stati o jazykovědě, protože to měli na nějakém zubařském školení. Tak jsem mu stručně vyložil jejich obsah, když jsem zrovna nemél nástroje v ústech." “46

V reakci na Stalinův zásah do jazykovědného vývoje došlo u nás v letech 1951-1952 k bouřlivé diskusi v periodicích Tvorba, Rudé právo a Slovo a slovesnost. Ideologická kampaň proti marrismu se však zvrtla spíše $\mathrm{v}$ boj o pražský strukturalismus a nejen lingvistická scéna byla svědkem do té doby stěží uvěřitelného divadla. Strukturalismus byl označován za idealistický, ahistorický, odmítající provázanost jazyka a myšlení, odtrhující vývoj jazyka od dějin společnosti a uváděn do př́mé souvislosti s marristickými myšlenkami. ${ }^{47}$ Nejaktivněji se do této diskuse zapojili Petr Sgall, František Trávníček, Bohuslav

40 Gustav BAREš a kol., Ohlas článku J. V. Stalina „O marxismu v jazykovědě“ na našich vysokých školách, Praha 1951, s. 72.

41 Srov. např. Milka Ivić, Wege der Sprachwissenschaft, München 1971, s. 95.

42 Srov. Adolf KELLNER - Bořivoj NovÁK (edd.), Sovětská diskuse o základních otázkách jazykovědných: Soubor diskusnich statí z listu Pravda a z čas. Bolševik, Praha 1951.

43 Viktor Vladimirovič Vinogradov, Geniální program marxistické jazykovědy, Praha 1951, s. 5.

44 Josif Vissarionovič Stalin, O marxismu v jazykovědě, Praha 1951.

45 Vladimír Macura, Št’astný věk: symboly, emblémy a mýty 1948-1989, Praha 1992, s. 53.

46 Rozhovor s Dušanem Šlosarem, in: J. Chromý - E. LehečKovÁ (edd.), Rozhovory, II, s. 294.

47 Např. Vladimír Barnet viděl oporu pro marristický princip stadiálnosti ve vývoji jazyka a myšlení v článku Bohumil TRNKA, Obecné otázky strukturálního jazykozpytu, SaS 9/2-3, 1943, s. 57-68, zde s. 57 a 58, kde se píše: „Historická kontinuita jazyka je nám př́stupná jen srovnáním jeho stadií, která ji svírají mezi sebou. Čím více je těchto stadií, tj. čím kratší jsou kontinua mezi jednotlivými příčnými průřezy, tím pravděpodobnější jsou výsledky našeho zkoumání minulých skutečností [...]. Absolutní kontinuum, jehož krajní mezí by byla nulová 
Havránek, Jaromír Bělič, Vladimír Barnet a Vladimír Skalička. Propagandistickým zpestřením dlouhých lingvistických disputací byl např. výstup pelhřimovského učitele Miloslava Polanského, který coby posluchač pražské pedagogické fakulty v letech 1948-1950 dle svých slov stále pocit’oval vlivy „lživědeckého strukturalismu“.48

Zatímco Bohuslav Havránek a Vladimír Skalička k diskusi přistupovali obezřetně a sebekriticky, ve snaze ubránit z pražských funkčně-strukturálních pozic, potažmo ze své strukturalistické práce ${ }^{49}$ co nejvíce, František Trávníček, Jaromír Bělič i Vladimír Barnet odmítali strukturalismus $\mathrm{v}$ zásadě jako celek. Za úhlavního nepřítele marxistické jazykovědy byl pak zejména Petrem Sgallem (za souhlasu většiny ostatních diskutujících) označen za války emigrovavší Roman Jakobson, ${ }^{50}$ člen Pražského lingvistického kroužku, jenž prý coby „protisovětský emigrant, kosmopolita a skrytý trockista“51 sváděl ostatní lingvisty na scestí a po válce „přešel do služeb amerického imperialismu“. ${ }^{52}$

Celá tato ideologická kampaň měla dle důvěrné zprávy referenta odboru vědy při kulturním a propagačním oddělení sekretariátu ÚV KSČ ze srpna 1951 přimět rektora Jana Mukařovského a děkana Bohuslava Havránka k otevřené sebekritice své strukturalistické minulosti a zjevnému př́iklonu k marxismu. ${ }^{53}$ Útočné články týdeníku Tvorba proto cílily i prímo proti pražské filozofické fakultě a jejímu vlažnému př́stupu k ideologickému boji. Děkan Bohuslav Havránek se tu nicméně ve své odpovědi pokusil odvrátit pozornost od strukturalismu (a Romana Jakobsona, svého dobrého př́tele, s nímž udržoval písemný kontakt ${ }^{54}$ zdůrazněním, že fakulta se ideologického boje nezrríká, naopak se nyní její katedra marxismu-leninismu zaměřuje na „odhalováni positivismu jako nejrozšírenějšího a nejnebezpečnějšího směru buržoasni filosofie“. .55

Navzdory bojovné názorové výměně, již Stalinovy stati vyvolaly a která ukázkově dokumentuje míru dobové absurdnosti, proti níž prakticky nebylo možné se veřejně ohradit, jim nelze upř́i jistý pozitivní význam. Jednak představovaly jediný účinný prostř̌edek, jak vysvobodit jazykovědu ze spárů nesmyslných marristických teorií, jednak se staly prostředkem k určité rehabilitaci společenskovědních disciplín s lingvistikou v čele, jimž začala být po roce 1948 připisována $\mathrm{v}$ ostentativním porovnání např. s průmyslovou výrobou společenská neužitečnost. To však již nebylo možné ríci v situaci, kdy něčemu věnoval pozornost sám velký Stalin. ${ }^{56}$

délka času mezi jazykovými stadii, nebude moci býti nikdy zjištěno, poněvadž to předpokládá nekonečnost etap“. Podle Petra Sgalla neviděl strukturalismus rozdíl mezi jazykem a kulturou, což plně korespondovalo s marristickým prohlašováním jazyka (stejně tak jako kultury) za součást ideologické nadstavby. Jaromír Bělič pak hledal paralelu mezi funkčními jazyky Pražské školy a marrovskými třídními jazyky.

48 Miloslav PolanskÝ, K diskusi o strukturalismu, Tvorba 20/44, 1951, s. 1062.

49 Skalička byl především nucen bránit svou světově průkopnickou typologii jazyků, již v této debatě přímo odsuzoval František Trávníček.

50 Ačkoli již v roce 1956 Petr Sgall ve svém článku ve Slově a slovesnosti 17/3, s. 181, svůj postoj značně přehodnocuje a svých ostrých prohlášení lituje, Roman Jakobson mu nikdy neodpustil, srov. např. Rozhovor s Františkem Danešem, in: J. CHRoмÝ - E. LehEč́ová (edd.), Rozhovory s českými lingvisty, I, Praha 2007, s. 21.

51 Petr SGaLl, Stalinovy práce o jazykovédè a pražský linguistický strukturalismus, Tvorba 20/28, 1951, s. 674.

52 František TrÁvníčEK, Strukturalismus - nepřitel naši jazykovédy, Tvorba 20/37, 1951, s. 893.

53 J. Havránek - Z. Pousta, Dějiny Univerzity Karlovy, IV, s. 442.

54 Kontakt s Romanem Jakobsonem však v této době na několik let raději bez varování přerušil, srov. M. HAVRÁNKOVÁ - J. TOMAN (edd.), Quadrilog.

55 Bohuslav Havránek - Oldřich Říha - Antonín Salač, Odpověd’ ke kritice v Tvorbě, Tvorba 21/48, 1952, s. 1158 .

56 Srov. Rozhovor s Miroslavem Komárkem, in: J. ChromÝ - E. LeHEČKová (edd.), Rozhovory, I, Praha 2007, s. 163. 


\section{Marxistická jazykověda}

V roce 1976 okomentoval Bohuslav Havránek ve svém rozhovoru s Pavlem Novákem debaty vedené ohledně zaměření časopisu Slovo a slovesnost větou: „P řed válkou nám vytýkali, že jsme marxisti, po válce, že jsme kontramarxisti." "57 Nepochybně si byl - obzvláště po překonání období marrismu a boje proti (pražskému) strukturalismu - vědom neurčitosti propojení slov marxismus a jazykověda a umně jím zastřešil svou postupnou obhajobu strukturální lingvistiky i rozvoj nových oborů a disciplín v 60. letech.

Poté, co došlo ke Stalinově demytizaci na XX. sjezdu KSSS v únoru 1956, odpoutávala se od stalinismu mj. i československá lingvistika. Na sklonku roku 1956 zorganizoval Havránek konferenci s názvem „O vědeckém poznání soudobých jazykư“, kde bylo pražské strukturalistické tradici zpětně přiznáno mezinárodní uznání (byt' zmínka o souvislosti s marxismem nechyběla) a obhájeno synchronní studium jazyků (integrálně doplňující genetický postup). V podobném duchu proběhly v relativně rychlém sledu další konference (o historickosrovnávací metodě, o dialektologii, o lexikografii), jejichž vrcholem byla v roce 1960 uskutečněná konference „Problémy marxistické jazykovědy“. Zde byl v zásadě bez větších př́kras shrnut dosavadní vývoj lingvistického myšlení u nás a z tzv. marxistických pozic uchopeny klíčové principy strukturální jazykovědy. Havránkovi bývá někdy podsouváno, ${ }^{58}$ že se po roce 1948 strukturalismu zřekl, ale jak potvrzuje ve své vzpomínce jeho žák František Daneš, „ve skutečnosti se ho nikdy nežrekl a všechny nás dál opatrně vedl v duchu Pražské školy“. ${ }^{59}$ Její další rozvíjení bylo nasnadě i proto, že proklamovaná marxistická orientace v jazykovědě nenabízela vůči (funkčnímu) strukturalismu ucelenější alternativu př́stupu ke zkoumání jazyka a nové, na Západě se konstituující metody neměly v Československu př́iliš šanci na uplatnění. ${ }^{60}$

\section{Šedesátá léta}

Liberálnější ovzduší šedesátých let poskytlo (nejen) jazykovědě určitý prostor k oproštění se od svazujících ideologických nánosů a do značné míry též předpoklad pro znovunavázání kontaktu s vědeckým vývojem v zahraničí. Vznik a rozvoj nových disciplín byl i přesto velkým dílem umožněn díky předvoji lingvistiky sovětské.

Ve druhé polovině padesátých let začínají ve světové jazykovědě uplatňovat svou metodologii matematické obory (např. kybernetika, teorie informace, statistika, teorie pravděpodobnosti, formální logika) a pod pláštíkem kompatibility s marxismem (zejména odkazem na zřetel $\mathrm{k}$ potřebám společnosti) si tato mezioborová vazba hledá své místo na slunci i u nás.

57 Pavel NovÁK, Konstanty a promény Havránkových metodologických postojů (se zvláštním zretelem $k$ jeho pojetí marxistické orientace v jazykovědě), Acta Universitatis Carolinae - Philologica 1-3, Slavica Pragensia XXXIV. Sborník k poctě stého výročí narození akademika Bohuslava Havránka, Praha 1990, s. 21.

58 Viz např. Václav ČERnÝ, Paměti, III, (1945-1972), Brno 1992, např. s. 120, 272.

59 Rozhovor s Františkem Daně̌em, in: J. Chromý - E. LehečKová (edd.), Rozhovory, I, Praha 2007, s. 20.

60 Blíže o tom viz Petr Karlík - Jana Pleskalová, Historie oboru: jaký má smysl pro současnost?, Naše řeč 93/4-5, 2010, s. 171-176. 
Prvního institucionálního zabezpečení v Československu se matematická lingvistika dočkala na pražské filozofické fakultě, kde bylo v roce 1959 při katedře českého jazyka, obecného jazykozpytu a fonetiky FF UK vedené Bohuslavem Havránkem zřízeno oddělení pro teorii strojového překladu, jehož vedoucím se stal Petr Sgall. Oddělení přitom vzniklo ze skupiny lingvistů, soustředěných kolem Bohumila Palka a Petra Sgalla, kteří se dané problematice na fakultě věnovali již nejméně v předchozích dvou letech. ${ }^{61} \mathrm{~V}$ návaznosti na rozvoj a stabilizaci specializovaných disciplín na fakultě ${ }^{62}$ se v roce 1963 přistoupilo $\mathrm{k}$ rozdělení bohemistické katedry na katedru českého a slovenského jazyka, jejíž vedení bylo svěřeno Aloisi Jedličkovi, a katedru obecné lingvistiky a strojového překladu, již vedl Vladimír Skalička. ${ }^{63}$

Na již zmiňované konferenci „Problémy marxistické jazykovědy“ (1960) se prvně hovořilo i o nových algebraických a kvantitativních metodách v lingvistice. Př́spěvky Matematické metody a marxistická jazykovéda ${ }^{64}$ a Význam teorie informace pro marxistickou jazykověd $u^{65}$ vytyčily konkrétní směry, jakými se může propojení matematických disciplín a lingvistiky ubírat. Vpravení této problematiky do vzájemného vztahu s marxismem jí v následujícím období poskytovalo ideologickou nedotknutelnost.

V roce 1960 ustavila VIII. sekce filologicko-literární ČSAV komisi pro aplikovanou lingvistiku $^{66}$ a v roce 1961 vzniklo i při Ústavu pro jazyk český oddělení pro matematickou a aplikovanou lingvistiku vedené Lubomírem Doleželem, které zacílilo svůj zájem na kvantitativní výzkum soudobé spisovné češtiny navazujíc na práce představitelů Pražské školy. Již v meziválečném období se totiž napríklad Vilém Mathesius, Bohumil Trnka či Josef Vachek zabývali kvantitativní analýzou fonémů.

Bohuslav Havránek prý sice původně matematickým metodám v lingvistice nakloněn nebyl, ale $\mathrm{k}$ jejich brzkému prosazování byl patrně veden i pragmatickým kalkulem, nebot' od počátku 60. let již čelil sílícímu tlaku, aby odešel do důchodu. Hrozbu proto takticky odvracel tím, že se postavil do čela nového př́stupu k jazykovědě, o který byl navíc v důsledku jeho rozvoje v SSSR živý zájem i mezi československými stranickými představiteli. ${ }^{67}$

V šedesátých letech se do jazykovědných bádání opatrně vkrádá také sociolingvistický aspekt a není překvapením, že prostor pro něj se otevíral spíše v Ústavu pro jazyk český nežli na fakultě. Vrcholem těchto tendencí byla roku 1968 započatá (politickým vývojem zakrátko utnutá) spolupráce ÚJČ s Ústavem pro výzkum veřejného mínění ČSAV. Díky ní byl prováděn výzkum postojů uživatelů jazyka k pravopisu či $\mathrm{k}$ přejatým slovům v české slovní zásobě s cílem jednak jazykově zefektivnit vyjadřování v hromadných

61 Pavel Novák, K poválečným osudiom české lingvistiky, SaS 52/3, 1991, s. 188.

62 Např. 1960/1961 bylo při katedře dějin hudby ustaveno oddělení dějin divadla; katedra rusistiky se 1960 rozpadla na katedru ruského a ukrajinského jazyka a katedru ruské a sovětské literatury; 1962 se katedra anglistiky a germanistiky rozdělila na katedru anglistiky a katedru germanistiky.

63 J. Havránek - Z. Pousta, Déjiny Univerzity Karlovy, IV, s. 456.

64 Petr Sgall - Pavel Novák, Matematické metody a marxistická jazykovéda, in: Problémy marxistické jazykovědy, Praha 1962, s. 41-50.

65 Lubomír Doležel, Význam teorie informace pro marxistickou jazykovědu, in: Problémy marxistické jazykovědy, Praha 1962, s. 51-67.

66 AAV ČR, fond VIII. sekce filologicko-literární, k. 17, i. č. 41, Zř́izení komise pro aplikovanou lingvistiku, 1960.

67 Rozhovor s Marii Téšitelovou, in: J. Chromý - E. LeheČKovÁ (edd.), Rozhovory, I, Praha 2007, s. 266-267. 
sdělovacích prostředcích, jednak prošetřit možnosti využití empirických sociologických metod $\mathrm{v}$ jazykovědě. 68

\section{Vazby Ústavu pro jazyk český ČSAV a Filozofické fakulty UK}

Ve druhé polovině 60. let přednášela téměr̆ třetina všech vědeckých pracovníků ČSAV na vysokých školách, zatímco množství pracovníků a studentů vysokých škol se běžně účastnilo odborných úkolů akademie. ${ }^{69} \mathrm{Na}$ bilaterální úrovni se odvíjely také vazby ÚJČ a FF UK.

Lingvisté působící na fakultě se jako řešitelé účastnili úkolů státního plánu výzkumu koordinovaných ÚJČ, ujímali se vědecké redakce, edice či recenzování ústavních publikací (slovníků, mluvnic, pravidel pravopisu apod.), zasedali v redakcích periodik vydávaných péči ÚJČ, v odborných ústavních komisích či měli možnost využívat ke své práci materiálové sbírky ÚJČ. Akademičtí jazykovědci naproti tomu na fakultě pravidelně i př́iležitostně přednášeli, vedli a oponovali kandidátské a diplomové práce, byli vybíráni za členy komisí pro závěrečné a státní rigorózní zkoušky a pro obhajoby kandidátských prací či se autorsky podíleli na koncipování učebních skript.

V šedesátých letech se vzájemná spolupráce Ústavu pro jazyk český a pražské filozofické fakulty významně rozšriřila i díky pořádání pověstných pravidelných ústavních seminářů. Scházela se na nich široká lingvistická obec a nebylo neobvyklé, že jejich hosty byli i významní zahraniční lingvisté. Probíhaly zde prezentace výsledkủ bádání ústavních i neústavních pracovníků, referovalo se o vývoji v domácí i světové lingvistice (např. o Chomského gramatických modelech), o nových publikacích, mladým kolegům byl otevřen prostor k zapojení se do odborných diskusí. Bez nadsázky je možné říci, že se tu scházela skutečná lingvistická elita (včetně té nastupující) tehdejšího Československa, ${ }^{70} \mathrm{z}$ větší části se hlásící k odkazu Pražského lingvistického kroužku.

Když bylo naopak na FF UK roku 1961 otevřeno dvouleté postgraduální studium aplikované lingvistiky, nastoupila do něj i početná skupina zaměstnancủ ÚJČ: František Daneš, Miloš Dokulil, Josef Filipec, Zdeňka Hrušková, Hana Kafková, Marie Ludvíková, Eva Macháčková, Jiří Marvan, Jan Průcha, Jitka Štindlová, Antonín Tejnor a Marie Těšitelová. ${ }^{71}$

Řada jazykovědců působila bud' stř́ídavě, či souběžně na fakultě i v akademii. Např. František Ryšánek od roku 1945 přednášel na FF UK, ale se vznikem ČSAV zasedl také ve vědecké radě ÚJČ a 1955 byl zvolen akademikem. Významně se účastnil odborného vedení prací na Staročeském slovniku v ÚJČ. Václav Vážný, který na FF UK odchoval řadu vynikajících dialektologů, se autorsky podílel na vzniku Českého jazykového atlasu při ÚJČ. Poválečný vedoucí oddělení pro studium nové spisovné češtiny ÚJČ Alois Jedlička se

68 AAV ČR, fond ÚJČ ČSAV, neuspořádáno, k. č. 50, Zápis ze schůzky pracovníků Ústavu pro jazyk český zajímajících se o spolupráci s Ústavem pro výzkum veřejného mínění (UUVVM) v otázkách jazykovědných ze dne 31. 10. 1969.

69 Srov. František Šorm, Věda v socialistické společnosti, Praha 1967.

70 Bohuslav Havránek, Josef Vachek, František Daneš, Miloš Dokulil, Josef Filipec, Marie Těšitelová, Karel Hausenblas, Igor Němec, Zdeněk Hlavsa, Jan Kořenský, Nad’a Svozilová, Iva Nebeská, Anna Jirsová, Lída Uhliřrová, Jiř́i Kraus, Oldřich Uličný a další.

71 Archiv Univerzity Karlovy (dále jen AUK), fond FF UK, k. 552, i. č. 1830, Postgraduální studium aplikované lingvistiky. 
v roce 1963 stal vedoucím katedry českého a slovenského jazyka FF UK. Podobně i Karel Hausenblas začínal (bezprostředně po skončení studia) v roce 1949 v ÚJČ a v roce 1961 přešel na FF UK. Děkan Filologické fakulty Univerzity Karlovy v letech 1955-1959 Karel Horálek, dlouholetý vedoucí katedry slavistiky, byl v roce 1956 zvolen členem korespondentem ČSAV a v 70. letech se stal ředitelem ÚJČ. Jaromír Bělič, jenž v roce 1957 přešel z olomoucké univerzity na pražskou, si v ÚJČ zajistil značný vliv skrze své místopředsednictví v VIII. sekci filologicko-literární ČSAV a následně předsednictví v akademickém Vědeckém kolegiu jazykovědy.

Specifická personální provázanost panovala mezi oběma pražskými fonetickými pracovišti, Fonetickým ústavem FF UK a Fonetickým kabinetem při ÚJČ ČSAV. Bohuslav Hála, který působil na FF UK od samotného založení zdejšího fonetického ústavu Josefem Chlumským v roce 1920, stál rovněž u zrodu akademického fonetického kabinetu. V padesátých letech vedl obě pracoviště najednou (fakultní interně, akademické externě) a stejným způsobem řídil pražskou fonetiku i jeho nástupce Milan Romportl.

V roce 1959 byl zvažován návrh na vytvoření velkého samostatného fonetického ústavu v rámci ČSAV sloučením dosavadních dvou pracovišt', zatímco na fakultě by zůstala jen malá skupina zaměřená víceméně pouze na výchovu mladých fonetiků. ${ }^{72} \mathrm{~K}$ realizaci této myšlenky však nedošlo i díky tomu, že české fonetické centrum bylo (nejen z hlediska delší tradice, ale i rozsáhlých, mezinárodně uznávaných výsledků své činnosti) právě na filozofické fakultě.

Součinnost fakultní a akademické fonetiky byla nicméně širokospektrá, prakticky se promítla např́íklad při vydávání ortoepických pravidel českého jazyka, ${ }^{73}$ ale i ve společném pořádání VI. mezinárodního kongresu fonetických věd v Praze v roce 1967, jehož prezidentem byl jmenován Bohuslav Hála, generálním sekretářem Milan Romportl a jako její výkonní sekretáři působili Přemysl Janota z FF UK a Jana Ondráčková z ÚJČ. ${ }^{74}$

Je však příznačné, že Bohuslav Hála zakončil svou bohatou vědeckou kariéru v Ústavu pro jazyk český, kam byl plně převeden v roce $1964,{ }^{75} \mathrm{kdy}$ dosáhl důchodového věku a na fakultě byl vzhledem $\mathrm{k}$ tomu již považován za nežádoucího. ${ }^{76}$

\section{Centrální postavení Ústavu pro jazyk český}

Ústav pro jazyk český se v daném období nacházel - podobně jako řada dalších akademických ústavů - v mnohostranně výhodnější pozici nežli jeho oborově nejbližší vysokoškolský protějšek (v prrípadě pražské filozofické fakulty šlo doslova o protější stranu mostu/ řeky, nebot’ hlavní sídlo FF UK na dnešním náměstí Jana Palacha a umístění ÚJČ v Letenské ulici od sebe dělí prakticky jen Mánesův most). Pražská filozofická fakulta byla zejména v padesátých letech vystavena tvrdým mocenským zásahům (likvidace akademických

72 AAV ČR, fond VIII. sekce filologicko-literární ČSAV, k. č. 11, i. č. 22, Zápis o zasedání vědecké rady ÚJČ ČSAV ze dne 24. 3. 1959.

73 Bohuslav Hála, Výslovnost spisovné češtiny, její zásady a pravidla, I, Výslovnost slov českých, Praha 1955 (2. vydání 1967).

74 Věra DvořÁčKovÁ, Osudy Ústavu pro jazyk český, Praha 2011, s. 150.

75 AUK, fond FF UK, k. 22, i. č. 256, Bohuslav Hála.

76 Srov. Rozhovor se Zdenou Palkovou, in: J. СнRомÝ - E. LeheČKovÁ (edd.), Rozhovory, II, s. 213. 
svobod a práv, personální čistky, redukce vědeckovýzkumné činnosti atd.), jejichž motivem bylo maximální ideologické podrobení fakulty. A ačkoli režim nebyl s výsledkem svého působení ve vysokoškolské oblasti př́liš spokojen, $v$ akademii věd se přeci jen dýchalo lépe.

Byl si toho dobře vědom i hlavní protagonista poválečného dění v československé lingvistice Bohuslav Havránek. Propojení svého vlivu na fakultě i v ÚJČ (potažmo v celoakademických strukturách) využíval jak ve prospěch bohemistické katedry, kde navzdory čistkám dokázal soustředit kvalitní pedagogický tým, tak především Ústavu pro jazyk český, kde bylo možné v daleko větší šíri rozvíjet vědeckou individuální i kolektivní práci, nepřetíženou ideologickým podtextem. Nejlepším ze svých studentů dokázal zajistit zaměstnání zpravidla v ÚJČ, což mělo za následek situaci, že zdejší kolektiv tvořil skutečný výkvět české jazykovědné bohemistiky.

K Havránkovým talentovaným studentům, již se po studí́ch přičiněním svého učitele ocitli v ÚJČ, patřili např. Jaroslav Kuchař, František Daneš, Karel Hausenblas, Lubomír Doležel, ale i původně brněnští studenti Bohuslava Havránka František Váhala, Miloš Dokulil či Karel Horálek.

Ústav pro jazyk český se pod Havránkovým vedením vyprofiloval v lingvistické pracoviště ústředního charakteru a významu, které bylo zároveň schopno plnit požadavek propojení s praxí (,protože praxe je marxistické gnoseologii verifikací poznáni"“77). Jazykovou revizí ÚJČ procházely všechny veřejně důležité texty (zákony, vyhlášky, mezinárodní smlouvy a dohody, nejrůznějšs r rády, směrnice, stanovy). ${ }^{78}$ Velmi rozsáhlá byla poradenská a konzultační činnost ÚJČ: v Praze i v Brně fungovala jazyková poradna odpovídající na písemné a telefonické dotazy, spolupracovalo se s úřady státní správy (např. s matrikami), s redakcemi novin a časopisů, Svazem českých novinářù, Československou televizí, Československým rozhlasem, Československou tiskovou kancelárí, Československým státním filmem atd. Pravidelně se přednášelo úředníkům, učitelům základních, středních i vysokých škol, redaktorům, novinářům, akademickým pracovníkům či dokonce armádním činitelům. Pořádaly se semináře z jazykové kultury, ale např. i z techniky jevištní mluvy a výslovnosti.

Pracovníci ÚJČ byli rovněž členy různých odborných komisí (zejména názvoslovných komisí Úřadu pro normalizaci a měření), v nichž i mimo ně pracovali na vytváření, stabilizaci a kodifikaci českého odborného názvosloví. Výsledkem jejich činnosti bylo zejména vydávání desítek státních názvoslovných norem, o něž byl zájem i v cizině (např. ze strany Rakouského normalizačního ústavu). ${ }^{79}$

Na půdě ÚJČ vznikla či v daném období vznikala (př́ípadně se k jejich budoucímu koncipování vytvářely podmínky) významná kolektivní díla, jež patří do základního fondu české/československé bohemistické produkce: všeobecné výkladové synchronní i diachronní slovníky češtiny, Český jazykový atlas, slovníky frekvenční, retrográdní, onomastické, Pravidla českého pravopisu, dvoudílné Tvoření slov v češtině atd. Vysoce cenné jsou rovněž mnohdy unikátní materiálové sbírky ÚJČ: novočeský a staročeský lexikální archiv, archiv lidového jazyka, nářeční fonotéka, rozsáhlá sbírka pomístních názvů, terminologické kartotéky, tzv. Český akademický korpus aj. V neposlední řadě je třeba se zmínit o původních

77 Lubomír DoležEL - Miloš Helcl, Konference o marxistické jazykovědě, SaS 22/2, 1961, s. 98.

78 Viz např. AAV ČR, fond ÚJČ ČSAV, neusporádáno, k. 2, Zpráva o plnění všech úkolů vědecké práce za rok 1957.

79 Miroslav RoudnÝ, Aplikovaná jazykověda v Ústavu pro jazyk český po roce 1953, in: Hana Barvíková (ed.), Věda v Československu v letech 1953-1963, Praha 2000, s. 293-294. 
jazykovědných teoriích ${ }^{80}$ vyvinutých v ÚJČ, jež svým významem dalece přesáhly nejen hranice Československa, ale i východního bloku.

\section{Bohuslav Havránek a jeho pozice}

Po skončení druhé světové války byl - zejména skrze své politické angažmá - vnímán jako nejvy̌̌ší představitel československé lingvistiky František Trávníček. V letech 1948-1960 byl poslancem Národního shromáždění, působil také jako rektor brněnské univerzity, člen ČSAV, vedoucí brněnské pobočky ÚJČ či jako předseda VIII. sekce filologicko-literární ČSAV. Pověsti nejvýznamnější vědecké autority v oblasti filologických oborů se však jednoznačně (a oprávněně) těšil Bohuslav Havránek, zakladatel a dlouholetý ředitel ÚJČ (podílel se i na založení Ústavu pro českou literaturu), člen ČSAV, děkan Filozofické (a posléze Filologické) fakulty Univerzity Karlovy, vedoucí bohemistické katedry FF UK, rektor Vysoké školy ruského jazyka, člen vědeckých rad Slovanského ústavu, Československo-sovětského institutu či Kabinetu filologické dokumentace. Jeho schopnosti jej však předurčovaly $\mathrm{k}$ vykonávání nesčetného množství dalších pozic a úkolů: zastával funkci vedoucího redaktora Slova a slovesnosti, byl členem redakce časopisů Slavia, Naše $\check{r}$ rě, Naše věda, Slovanský přehled, Byzantinoslavica, Zeitschrift für Phonetik, Sprachwissenschaft und Kommunikationsforschung (Berlin), Acta linguistica Hafniensia (Kodaň) či Word (New York). Redigoval významná kolektivní díla, např. Přiruční slovník jazyka českého, Velký rusko-český slovník, Staroslověnský slovnik, Československou vlastivědu (svazek Jazyk), Památky staré české literatury, Dílo J. A. Komenského, Spisy Boženy Němcové, ale také edici polské bible královny Žofie. Aktivně se účastnil prací ve Svazu československých spisovatelů a Společnosti pro širření politických a vědeckých znalostí.

Na světovém vědeckém fóru platil za uznávaného spoluzakladatele pražské lingvistické školy, což plně korespondovalo s jeho členstvím v mezinárodních organizacích (např. Comité International Permanent des Linguistics, Société de Linguistique de Paris, The International Linguistic Association, The Linguistic Circle of New York). Byl rovněž předsedou Mezinárodního komitétu slavistů a řady jeho komisí (mezinárodní komise pro studium gramatiky slovanských jazyků, mezinárodní komise pro Slovanský jazykový atlas, komise pro církevněslovanský slovník, komise pro studium spisovných slovanských jazyků a komise gramatické), předsedou národního Československého komitétu slavistů a Československo-polské lingvistické komise ČSAV a PAN. Za člena byl zvolen také v rámci Bulharské akademie věd v Sofii, Srbské akademie věd a umění v Bělehradě, Německé akademie věd v Berlíně, Saské akademie věd v Lipsku, Rakouské akademie věd ve Vídni, Britské akademie v Londýně, čestný doktorát mu udělila Univerzita J. E. Purkyně v Brně, Univerzita F. Palackého v Olomouci, Univerzita K. Marxe v Lipsku či Jagellonská univerzita v Krakově.

Po vyjití Stalinových jazykovědných statí se Trávníček i Havránek do následné diskuse zapojili, i když každý zvolil jiný př́stup. Zatímco Havránek, jak již bylo výše řečeno, se svého strukturalistického zaměření nikdy nevzdal a dovedně jej vzdor dobové nepř́ízni více či méně nápadně ospravedlňoval, Trávníček proti strukturalismu nesmlouvavě brojil a ze

80 Např. slovotvorná teorie Miloše Dokulila, Danešova teorie větné intonace, koncepce systematické analýzy slovesných významů z hlediska syntaktického i sémantického, Danešova teorie tematických posloupností a další. 
svého stalinismem ovlivněného postoje nikdy neustoupil (a zůstal v něm v zásadě osamocen), čímž u lingvistické veřejnosti výrazně pozbyl na vážnosti.

Havránek zůstal naopak všeobecně ctěn především pro své odborné kvality, organizační schopnosti i názorovou konzistenci, byt' ochranářsky překrývanou ideologickými požadavky marrismu, poté stalinismu a nakonec hledání marxistické orientace v jazykovědě. Včlenění ideologicky podbarvené poučky či citace žádoucího (zpravidla sovětského) badatele na viditelné místo $\mathrm{v}$ textu bylo ostatně zcela běžnou praxí, bez níž by řada jinak velmi hodnotných prací nebyla vůbec publikována.

V názoru na Havránkovu osobnostní charakteristiku se v existující publikované literatuře rýsují dva protichůdné názory a je třeba říci, že postoj veskrze negativní, jemuž vévodí Paměti Václava Černého, se vyskytuje ve výrazné menšině. Černého hodnocení (dané osobní křivdou) stojící si za Havránkovou amorálností a machiavellistickým přístupem podtrhují i slova Jindřicha Tomana ${ }^{81}$ a Vladimíra Šmilauera. ${ }^{82}$ Patrně též historik Václav Vojtíšek se na Havránka nedíval s př́lišnou důvěrou. ${ }^{83}$

Naproti tomu velká část Havránkových kolegů a studentů ${ }^{84}$ při zpětném pohledu hodnotí jeho osobnost velmi prŕznivě, oceňuje nejen jeho odbornou univerzálnost, jazykový cit, pečlivost a nezměrnou pracovitost, ale právě i jeho charakterové vlastnosti, které v prŕhodném propojení se strategickým uvažováním stály za záchranou (nejen) profesního života celé řady Havránkových současníků ${ }^{85}$ např. Josefa Filipce, Františka Václava Mareše, Františka Kopečného, Františka Ryšánka, Václava Vážného, Ĺudovíta Nováka či Josefa Vachka, jenž sám uvádí: „právě Havránek, který své spolupracovníky vždy cenil především podle jejich poctivé vědecké práce, dovedl mnoha lidem, kteři stranickým ideovým normám nehověli, vjejich nesnázích velmi účinně pomáhat. Proto právějen on dovedl zklidnit postmarristický zmatek, i když si to ovšem vyžadovalo nějaký čas. "86

\section{Závěr}

Pozice Bohuslava Havránka byla pro směřování české, respektive československé jazykovědy v poválečném období vskutku určující. Svých mimořádných schopností přitom využíval nejen k prosazení svých ambicí (zastával množství klíčových funkcí), ale i k zabezpečení - v rámci dobových možností - organického vývoje v lingvistice a zčásti či nepř́imo i v některých oborech jí příbuzných. Mezi akademickým Ústavem pro jazyk český a jazykovědným bohemistickým pracovištěm FF UK panovaly úzké vazby, které vyplývaly i z Havránkovy personální politiky. Byl si vědom toho, že kvalitní odborníky, jimiž chtěl

81 Jindřich Toman, Přiběh jednoho moderního projektu: Pražský lingvistický kroužek, 1926-1948, Praha 2011, s. 148.

82 Martina Šmejkalová, Praporu věren i ve ztraceném boji. Vladimír Šmilauer - život a dílo filologa (1895-1983), Praha 2015, s. 542-545 (Príloha 2).

83 Rozhovor s Františkem Daně̌em, in: J. Chromý - E. LehečKová (edd.), Rozhovory, I, s. 24.

84 Např. Josef Vachek, František Daneš, Pavel Trost, Miloš Pohorský, Jiří Kraus, Iva Nebeská, Zoe Hauptová, Lubomír Doležel a další.

85 Viz např. Otakar Mališ, Josef Filipec jubilující, SaS 61/1, 2000, s. 75; Rozhovor se Zoe Hauptovou, in: J. CHROmÝ - E. LehečKová (edd.), Rozhovory, II, s. 48-49; Marie Havránková - Vladimír Petkevič (edd.), Pražská škola $v$ korespondenci: dopisy z let 1924-1989, Praha 2014, 796 s.

86 Josef VAcher, Prolegomena k dějinám Pražské školy jazykovědné, Jinočany 1999, s. 68. 
zabezpečit vědeckovýzkumnou činnost jak na Univerzitě Karlově, tak především v ÚJČ, může dobře vychovat jen kvalitní pedagogická základna. I s ohledem na to pak často bránil pozice těch vyučujících, již se ocitali v důsledku stranické politiky v ohrožení. A pokud se mu nepodařilo je na fakultě udržet, dokázal je zpravidla umístit na některé z pracovišt' akademie. Díky jeho působnosti byl jak na filozofické fakultě, tak v ÚJČ zajištěn sbor vynikajících lingvistů, $\mathrm{z}$ nichž se řada $\mathrm{v}$ průběhu sledovaného období objevila stř́́davě, či zároveň na obou těchto pracovištích. Ve srovnání s ÚJČ však byla fakulta vystavena většímu ideologickému tlaku a z něho vyplývajícím restrikcím, což v součinnosti s tehdejším způsobem organizace vědy přispělo $\mathrm{k}$ tomu, že právě z Ústavu pro jazyk český vybudoval Havránek instituci centrálního rázu a významu. V př́hodné symbióze se zde snoubilo vyhovění dobovému požadavku propojení vědy a praxe (skrze činnost poradenskou, korektorskou, konzultační, přednáškovou a další) s rozvíjením nejlepších tradic domácí lingvistiky v podobě pražského (funkčního) strukturalismu. Výjimečné postavení mělo v tom ohledu fonetické pracoviště FF UK, které si své výsostné postavení v oboru, sahající hluboko do období první Československé republiky, uchovalo.

VĚRA DVOŘÁČKOVÁ

\section{"Ohne Havránek lief gar nichts." Die Nachkriegsbeziehungen des Lehrstuhls für tschechische Sprache der Prager Philosophischen Fakultät und des Instituts für tschechische Sprache an der Akademie der Wissenschaften}

\section{ZUSAMMENFASSUNG}

Die Nachkriegsbeziehungen des Lehrstuhls für tschechische Sprache an der Philosophischen Fakultät der Karlsuniversität und des Instituts für tschechische Sprache an der Akademie der Wissenschaften in Prag waren sehr eng, und zwar sowohl in der wissenschaftlichen Forschung als auch in personaler Hinsicht. Der Charakter dieser Beziehungen wurde zu einem überwiegenden Teil von dem bedeutendsten Linguisten der damaligen Tschechoslowakei: von Bohuslav Havránek, bestimmt, der Dekan der Philosophischen Fakultät und Leiter des sprachwissenschaftlichen bohemistischen Lehrstuhls und gleichzeitig eines der ersten Mitglieder der Tschechoslowakischen Akademie der Wissenschaften und Direktor ihres Instituts für tschechische Sprache war. Seine Persönlichkeit, in der sich hohes Fachwissen mit natürlicher Autorität, taktischem Abwägen und der Fähigkeit verband, das Maß an Toleranz seitens des Regimes genauestens abzuschätzen, ließ ihn zur führenden Persönlichkeit der tschechischen/ tschechoslowakischen sprachwissenschaftlichen Bohemistik werden. Dabei reichte Havráneks Einfluss nicht nur in den Wirkungsbereich des Lehrstuhls für tschechische Sprache an der Philosophischen Fakultät der Karlsuniversität und des Akademie-Instituts für tschechische Sprache, sondern auch in weitere (und nicht nur Prager) Arbeitsstätten seines Faches und in fachverwandte Arbeitsstellen. Den meisten Raum bot ihm nichtsdestoweniger das Akademie-Institut für tschechische Sprache, das er gegründet hatte und zu einer zentralen Institution auszubauen verstand. Ermöglicht wurde ihm dies vor allem dadurch, dass dieses Institut weniger ideologischem Druck ausgesetzt war als die entsprechende Einrichtung an der Philosophischen Fakultät und er somit freier an die Entfaltung der Zwischenkriegstraditionen der bis heute international anerkannten Prager Schule anknüpfen konnte.

Deutsche Übersetzung Wolf B. Oerter

Věra Dvořáčková

Masarykův ústav a Archiv $A V \check{C} R$, v. v. $i$.

Ústav pro jazyk český $A V \check{C} R$, v. v. $i$.

vera.dvorackova@email.cz 